\title{
Evolution of the cell wall components during terrestrialization
}

\author{
Alicja Banasiak* \\ Department of Developmental Plant Biology, Institute of Experimental Biology, University of Wrocław, Kanonia 6/8, 50-328 Wrocław, Poland
}

\begin{abstract}
Colonization of terrestrial ecosystems by the first land plants, and their subsequent expansion and diversification, were crucial for the life on the Earth. However, our understanding of these processes is still relatively poor. Recent intensification of studies on various plant organisms have identified the plant cell walls are those structures, which played a key role in adaptive processes during the evolution of land plants. Cell wall as a structure protecting protoplasts and showing a high structural plasticity was one of the primary subjects to changes, giving plants the new properties and capabilities, which undoubtedly contributed to the evolutionary success of land plants.

In this paper, the current state of knowledge about some main components of the cell walls (cellulose, hemicelluloses, pectins and lignins) and their evolutionary alterations, as preadaptive features for the land colonization and the plant taxa diversification, is summarized. Some aspects related to the biosynthesis and modification of the cell wall components, with particular emphasis on the mechanism of transglycosylation, are also discussed. In addition, new surprising discoveries related to the composition of various cell walls, which change how we perceive their evolution, are presented, such as the presence of lignin in red algae or MLG $(1 \rightarrow 3),(1 \rightarrow 4)-\beta$-D-glucan in horsetails. Currently, several new and promising projects, regarding the cell wall, have started, deciphering its structure, composition and metabolism in the evolutionary context. That additional information will allow us to better understand the processes leading to the terrestrialization and the evolution of extant land plants.
\end{abstract}

Keywords: cell wall; evolution; land plants; terrestrialization; ancestral genes; polysaccharide; lignin

\section{Introduction}

Emergence of the land plants was one of the most important events in the history of life on the Earth, which happened about 480-470 million years ago [1-5]. It is generally accepted that land plants, including bryophytes and vascular plants, are a monophyletic group derived from ancient freshwater charophycean green algae (CGA) $[1,6,7]$. Their rapid expansion and diversification led to the changes in the atmosphere and soil composition, significantly affecting the development and evolution of all living organisms [8-10].

Currently, the vascular plants are a dominant group in terrestrial ecosystems, showing great diversity of structural and physiological adaptations [11]. The cell walls and their modifications undoubtedly played a key role in that evolutionary success. As a structure protecting the protoplasts and responding to extracellular conditions it contributed significantly to the plant adaptation to different environments, which changed during million years of evolution [6-8]. As a consequence, the plant cell walls are extremely variable in their structure, composition and ongoing metabolic

\footnotetext{
*Email: alicja.banasiak@uni.wroc.pl
}

Handling Editor: Beata Zagórska-Marek processes, depending on the plant phylogenetic position, developmental stage, cell type, or even the region within a single cell [12]. Regardless of this diversity, the essential components of the cell walls are carbohydrates. Cellulose is usually a major structural element forming supporting rigid network, while other polysaccharides, glycoproteins, enzymes and phenolic compounds form a matrix, in which this network is immersed [11,13-16]. Due to such a composition the cell wall is a tensegral structure, in which tensile and compressive forces are balanced giving its exceptional strength while maintaining the flexibility. Relatively well understood are the structure and the composition of the cell walls in seed plants, whereas in evolutionarily less advanced plant groups this knowledge is rather scarce. However in recent decades, the representatives of these plant groups have become the subject of exhaustive studies, in appreciation of their significance for understanding the origin of land plants, the mechanisms responsible for their radiation and the relationships between structure and function of various cell walls.

In this review, the main focus is on the polysaccharide components of the cell wall and on lignin, in the context of evolutionary changes (Tab. 1) associated with their significance for the land plant emergence and diversification. 


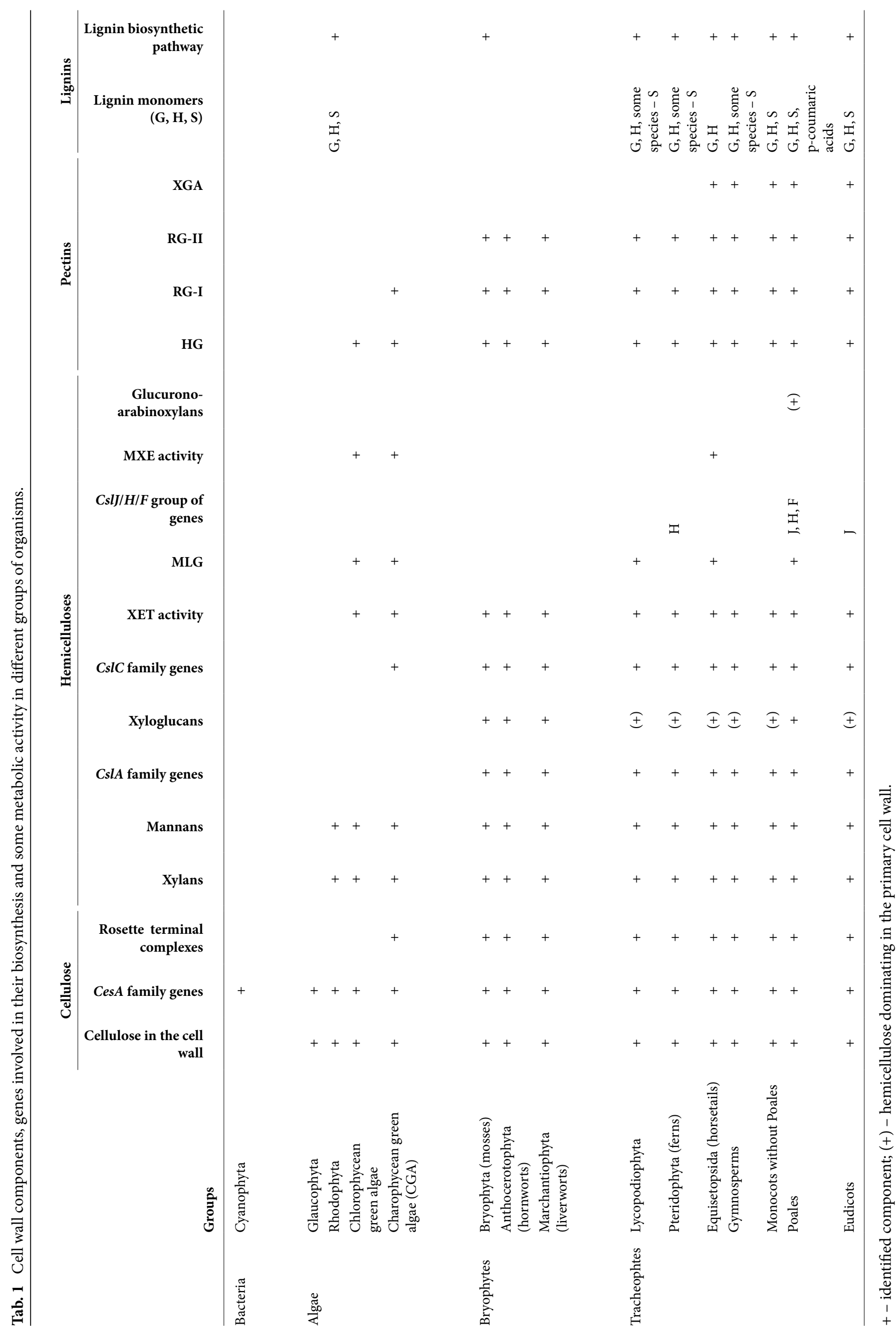




\section{The origin of the cell walls of land plants}

Polysaccharide-rich cell wall, in addition to the acquisition by eukaryotes the ability to conduct the photosynthesis, was a key innovation in plant development and evolution. It is suggested that both these events are the outcome of primary endosymbiosis [12,17], when a cyanobacteria penetrated the host cell, giving rise to the common ancestor of the Archaeplastida group [18], which includes glaucophytes, red and green algae, and land plants [19-21]. Although cyanobacteria cell walls are composed of peptidoglycan and differ from the polysaccharide-rich plant cell walls, it is hypothesized that endosymbiont genes, involved in carbohydrates biosynthesis, due to horizontal gene transfer, provided the molecular background for the cell wall formation in the land plant lineage [22].

New potentials achieved due to the primary endosymbiosis were later tested by the algae of Archaeplastida group in order to better protect sensitive protoplasts, resulting in high diversity of cell wall structures and compositions [10-23]. It seems that some of the new solutions gained became the pivotal point for terrestrialization, although most of the compounds and structural diversity of cell wall in extant terrestrial plants were established later, as innovations associated with their adaptive radiation and diversification [11].

\section{Cellulose - the main component of plant cell wall}

The fundamental component of the plant cell walls is cellulose, which is deposited outside the plasma membrane in the form of microfibrils, forming the extracellular network. This polysaccharide is synthesized by the complexes of membrane proteins called cellulose synthase, also named terminal complexes (TCs), which include catalytic subunits encoded by the CesA family genes [24-26]. In seed plants, TCs form hetero-oligomeric rosettes, supposedly consist of 36 catalytic subunits that synthesize 36 cellulose chains forming a single microfibril [27], although recent studies suggest that plant microfibril can contain only 18-24 cellulose chains [28].

Genes of the CesA family are supposed to be of the ancient cyanobacteria origin $[17,26,29,30]$. Results of the phylogenetic analyses showed that in CGA the Ces $A$ was a single gene, whereas already in basal land plants $\operatorname{Ces} A$ formed a single monophyletic group of genes. Following, due to the duplication and diversification events, many different Ces $A$ subfamilies have evolved in the vascular plants before the divergence of ferns [24,26]. The functions of Ces $A$ genes were conserved during the evolution, from the cyanobacterial endosymbiont, by algae ancestors of land plants, to extant groups of Tracheophyta [26,31], indicating the significance of cellulose for development and functioning of all plants.

Despite the ability of diverse plant organisms to synthesize cellulose, only one lineage colonized the land. In the ancestors of this lineage (CGA), for further successful terrestrialization seems to be crucial the structural change, which occurred in the terminal complexes. In CGA and all land plants the terminal complexes have a rosette shape [32]. In addition, the CesA in these TCs show high amino acid similarity and the presence of highly conserved domains [32].
In contrast, more ancestral chlorophycean green algae possess the linear, ancestral type of TCs [33]. This strongly suggests that the rosette complex was formed in CGA, as direct ancestors of land plants [32]. The reorganization of the TC structure from linear to rosette was possibly one of the evolutionary innovations which enabled the expansion to the terrestrial habitats but how this structural change has happened still remains unknown. As the domains that characterize the CesA family of seed plants, evolved before the emergence of land plants and were conserved from CGA to angiosperms, it is assumed that they play a pivotal role in maintaining the structure of the rosette complexes [32].

During evolution, Ces $A$ genes encoding the catalytic subunits of TCs were subjected to specialization [26], which in seed plants had occurred at least at two levels: first - specialization of entire complexes to cellulose biosynthesis for primary and secondary walls; second - diversification of CesA catalytic subunits within a single rosette and formation of hetero-oligomeric complexes [34]. The sequence of specialization events is a crucial aspect necessary for understanding the evolution of cellulose biosynthesis. A recent study on seed plants and a representative of mosses Physcomitrella patens, showed specialization of entire complexes in both these groups [32,35]. In seed plants, terminal complexes are specialized to form cellulose of primary and secondary cell walls, whereas in P. patens to deposit cellulose during apical and diffusive growth. Phylogenetic analyses showed that CesAs in P. patens and in seed plants are not orthologs. Thus, specialization of entire terminal complexes in these two groups had to occur independently. Their common ancestor had only one CesA gene, and unspecialized homo-oligomeric complexes, but these already forming the rosette structure of TCs. Therefore, functional specialization of entire terminal complexes occurred after the formation of rosettes [31]. Complexes specialized to produce primary and secondary walls evolved to hetero-oligomeric TCs due to the diversification of CesAs [31,34,36-39]. This second specialization event took place probably after the divergence of lycophytes, in a common ancestor of ferns and seed plants. Ces $A$ genes, already in ferns, form many subfamilies, which contain genes orthologous to that of extant seed plants, including orthologs of AtCesA4, AtCesA7 and AtCesA8, involved in secondary cell wall formation in Arabidopsis $[26,40]$. The emergence of hetero-oligomeric complexes in a common ancestor of seed plants [27] suggests their importance for the origin and diversification of this group of plants and for functional specialization at the cellular and tissue level.

\section{Polysaccharide components of the cell wall matrix}

The cell wall matrix is composed of different compounds, which determine cell wall properties [41]. In extant seed plants, significant differences in the matrix composition became the reason for the cell walls classification to two types [15]. Type I cell wall occurs in dicots, non-commelinoid monocots and in gymnosperms, and consists of cellulose microfibrils surrounded by the xyloglucan (XyG), pectins and structural proteins. Type II cell wall is characteristic only 
of commelinoid monocots; it contains cellulose fibrils coated with glucuronoarabinoxylan (GAX), very low concentrations of pectins and structural proteins, and also high level of hydroxycinnamic acids [42].

\section{Hemicelluloses - cellulose-binding glycans}

Hemicelluloses are especially important matrix components of the cell wall. Due to their complex structure and composition, which are specific for the taxonomic groups of plants, tissues, cells and layers of the wall, they are considered as the most diverse and variable components of the cell walls. According to the current models, they form connections between cellulose microfibrils and are a subject of various modifications affecting the properties of the cell walls $[11,12,22,43,44]$. In extant seed plants, the most important for the cell walls functioning are mannans, xyloglucans, $(1 \rightarrow 3),(1 \rightarrow 4)-\beta$-D-glucans (mixed-linkage glucans; MLG) and xylans [45]. These hemicelluloses were probably involved in the evolution of land plants affecting their adaptive abilities, beneficial during colonization of new habitats, as well as contributing to taxa diversification and functional specialization of the cells $[17,41,46,47]$.

MANNANS. Mannans are present in all land plants and probably were one of the first hemicelluloses to appear. Large amounts of mannan are found in the cell walls of all CGA and basal land plants [48-50]. However, in angiosperms mannans are much less common, suggesting that during the evolution of terrestrial plants, in parallel to increasing diversity and abundance of hemicelluloses, there was a tendency to reduce mannan level [49]. Mannans are present in all green algae and only in some red algae, which both however resulted from the same endosymbiotic events, but are not found in brown algae, differing in their origin. It is therefore speculated that the presence of mannans is responsible for the green algae diversity and evolutionary success [22].

Mannans can be of pure or more structurally complicated form, with a wide range of physicochemical properties, and therefore complex functions, which are poorly understood [51]. In some algae, mannans occur in crystalline form [52], forming mannan microfibrils, which replace the cellulose skeleton as the main structural component of the cell wall [53]. Mannans can be also enabling the formation of polysaccharide network by linking cellulose microfibrils [54]. In primary cell walls of seed plants, however, xyloglucan takes over this function as binding glycan, causing probably a decrease in mannans amount [55]. However, mannans structural role is still preserved in the secondary cell walls.

XYLOGLUCANS. Xyloglucan (XyG) is the dominant hemicellulose in primary cell walls of all seed plants [56], with the exception of commelinoid monocots, where the main hemicellulose is glucuronoarabinoxylan [15,42]. Since the presence of xyloglucan seems to be limited to land plants (embryophytes) it is believed that XyG may constitute an important evolutionary innovation [11]. It cannot be ruled out that this polysaccharide was present already in the CGA ancestors of land plants, however, the experimental results on xyloglucan detection in Chara are disputable [22,46,57].

The structural and biochemical analyses of XyGs revealed differences in their side chains and fucosylated subunit in different groups of plants [58-60]. Most vascular plants and hornworts produce the structurally homologous XXXG xyloglucan type, with the conservative pattern of branching and fucosylated subunit, although Poales and Solanales have low-fucose xyloglucan [59]. In non-seeds plants the xyloglucan structure exhibits greater variety. For example, basal bryophytes have a XXGGG- and XXGG xyloglucans containing $\beta$-D-galactosyluronic acid and branched xylose residues [58], while Equisetum and Selaginella have xyloglucan containing $\alpha$-L-arabionopyranose in place of many of the $\beta$-D-galactopyranose residues [39,58] (Tuomivaara et al. [61] xyloglucan oligosaccharide nomenclature). The presence of XXXG xyloglucan in only one bryophyte group - hornworts and in tracheophytes proves their sister relationship [58]. In addition, it suggests that this form of xyloglucan evolved in the direct ancestor of all vascular plants and therefore could be important for Tracheophyta emergence.

Commelinoid monocots, which include grasses, are the only group of angiosperms with small amount or even lack of xyloglucan. Instead they have the type II cell wall and glucuronoarabinoxylan as the dominating hemicellulose in their primary walls $[15,62]$. It is supposed that the formation of the type II cell wall in commelinoids has been a relatively recent event in plant evolution, related to some changes in the strategy of survival and adaptation to new habitats [63]. Such simultaneous rapid and extensive changes in the cell wall composition only in one group of plants and in relatively short time, leading to the type II cell wall formation, are difficult to explain. Furthermore, the major components and structure of the cell walls were rather conserved in seed plant evolution. It is speculated that even so complex changes could result from a small modification of one component, forcing other elements to adjust. This hypothesis can be supported by the experiments, showing that a small change in the chemistry of cell walls can drastically affect their structure and functioning due to the mutual relationship between the individual components [17].

MIXED LINKAGE GLUCANS. Cell walls of grasses (Poaceae), belonging to commelinoids, contain a rare hemicellulose called mixed-linkage glucan (MLG), which for a long time was believed to be unique for these plants $[42,62,64]$. However, with development of chemical, molecular and bioinformatic methods for cell wall analysis, it became evident that MLG is much more common in the plant kingdom than previously considered [64]. The most surprising was however the discovery of mixed glucan in horsetail Equisetum arvense [47,65] and Selaginella moellendorffi since Poaceae diverged several millions years after these plants $[40,66]$. These results were obtained by few independent research teams, with the use of different experimental approaches: detection of anti-MLG antibodies, as well as by biochemical analyzes $[40,47,65]$. Interestingly, that MLG was found in CGA and polysaccharide similar to MLG in algae Ulva lactuca and Ulva rigida belonging to Chlorophyta lineage [46]. The occurrence of MLG in so many different and evolutionary distant groups of plants is difficult to explain. It is suggested that the MLG presence might be related to the silica accumulations in the cell walls $[22,47]$. Poales and horsetails produce MLG and synthesize abundance of silica [67]. However, this hypothesis requires further research. 
XYLANS. Xylans are ubiquitous hemicelluloses of vascular plants [68], present mainly in their secondary cell walls $[69,70]$. Therefore, it was suggested that the acquisition of xylan synthesis capabilities could have been an evolutionary innovation of this group of plants $[49,68]$. However, xylans were also found in hornworts [68], mosses [48], CGA [57], chlorophycean green algae and red algae [71], suggesting that they are much more common. Nevertheless, it is still not known whether xylans present in these species are structurally similar to those of vascular plants [70]. Xylans have the $(1 \rightarrow 3)$ or $(1 \rightarrow 4)$ glycosidic linkages [72]. Some red algae, including relatively basal Bangia fuscopurpurea, have only $(1 \rightarrow 3)$ glycosidic bonds in xylans, while more evolutionary advanced, as e.g. Palmaria palmata, probably contain both types, $(1 \rightarrow 3)$ and $(1 \rightarrow 4)$ glycosidic linkages in the same molecule [72,73]. In contrast, more evolutionarily advanced CGA, including Charales, Coleochaetales and Zygnematales, as well as all land plants contain only $(1,4)-\beta$-D-xylan in their cell walls $[57,68]$. These findings suggest that CGA and terrestrial plants gained the ability of $(1,4)-\beta-D$-xylan biosynthesis from red algae, in which diverse xylan biosynthetic pathways were present [72].

The origins of the secondary cell walls with xylans, as main hemicelluloses, are not fully elucidated. Nevertheless, their evolution was probably an important preadaptive feature of vascular plants, that enabled the emergence of conducting and mechanical tissues, which allowed the plants to accelerate their growth and increase the biomass production $[11,49,68]$.

\section{Hemicellulose biosynthesis}

Matrix polysaccharides are encoded by CesA-like Csl genes that together with $\operatorname{Ces} A$ form a superfamily CesA/Csl [74]. In seed plants nine Csl gene groups are known [26]. According to recent phylogenetic studies, Csls derived from two ancestral genes, gained due to the primary endosymbiotic event [26]. The first of them - ancestral Csl, was the precursor of $C s l A / C / K$ families, while the second one - ancestral $\operatorname{Ces} A$, gave rise to both extant CesAs and to the remaining Csl families [26]. Csl genes are present in all land plant lineage genomes [75], and their diversification led to the evolution of hemicelluloses and diversity of terrestrial plants [12].

It is believed that duplication of the first ancestral Csl gene could have resulted in the separation of direct ancestors of monophyletic group of land plants - CGA from chlorophycean green algae [12], and thus it could be a key event for successful expansion to the land. In CGA, probably as a result of subsequent duplication, ancestral $C s l$ gene evolved to $C s l A$ and $C s l C$ genes [24]. In land plants, CslAs were reported as those involved in the mannan synthesis [76,77], while $C s l C$ in the xyloglucan synthesis [78]. Extant CGA contain mannans in their cell walls, but are devoid of the CslA genes, which were probably lost during evolution [26]. Therefore, the question remains unresolved, which genes in these organisms are responsible for the mannan synthesis. Mannans are present also in cell walls of chlorophycean green algae, where the ancestral $C s l$ is probably responsible for their biosynthesis [24]. It is therefore likely that because the CslA gene was lost, its function in CGA is executed by $C s l C$, especially that xyloglucan, which is synthesized in seed plants by $C s l C$, was not found in CGA [12]. Alternatively, in the synthesis of mannans in CGA, the CslD gene can be involved, which derived from a second ancestral gene CesA [26]. The exact role of CslD in CGA is not specified, but recent studies suggest that in seed plants CslD can be responsible for glucomannan synthesis $[45,79,80]$. Both these alternative assumptions indicate that in CGA, the ability to synthesis of mannans was emerged independently of CslA and is a result of convergent evolution.

CGA were the first group of plants, in which the CslC gene appeared and it is considered to be involved in the xyloglucan biosynthesis in seed plants [78]. Xyloglucan is crucial for the cell wall expansion [41], thus it is necessary for the plant growth and for the increase of plant size, which was an important tendency during land plant evolution. Because the presence of xyloglucan in CGA has not been clearly confirmed so far, it seems likely that in these algae, acquisition of $C s l C$ gene could be an important preadaptive innovation for further land expansion.

Duplication and diversification of the second ancestral gene - CesA, probably resulted in two genes, one of which was the last common ancestor of Ces $A / C s l D / F$ group and the second one of $C s l B / H / E / J / G$ group [26]. The ancestor of the first group subsequently duplicated and diverged to the CesA and $C s l D$ clades. Both of these genes appeared in CGA and were highly conserved during the evolution of land plants, indicating that their divergence could have been another important preadaptation to the life on the land, and that it can play a pivotal role in terrestrialization. Interestingly, probably as a result of next, relatively recent CslD duplication and further rapid divergence and diversification, a CslF gene family emerged [26]. Genes of this family are present only in some Poales [81].

The diversification of the ancestor gene for the second $C s l B / H / E / J / G$ group happened before the evolution of ferns. For this reason, it is believed that these genes are important not as much for the origin of land plants as rather for their radiation and diversification [26]. Interestingly, gymnosperms have no obvious homologues or orthologs of this gene group but have genes relatively basal to $C s l E / G$ and $\mathrm{CslB} / \mathrm{H}$, which are specific to gymnosperms. Because in ferns, which are phylogenetically older than gymnosperms, the $\mathrm{CslB} / \mathrm{H} / \mathrm{E} / \mathrm{J} / \mathrm{G}$ group of genes is present, it is postulated that gymnosperms lost these genes during evolution, although it is still not clear how [26]. Alternatively, it is suggested that gymnosperms have a lower rate of substitution in their genome and therefore a lower rate of evolution [82].

The function of the CesA/CslD/F and $C s l B / H / E / J / G$ group of genes remains largely unclear [26]. However, CslF, CslH and CslJ were shown to be involved in the biosynthesis of MLG [74,81-84]. These three gene families occur in Poales, which synthesize MLG. The CslF gene is unique for this taxon, while two other families ( $\mathrm{CslH}$ and $\mathrm{Csl}$ ) are also present in other groups of vascular plants [26], where MLG is not found. Therefore, it is possible that these genes may have some additional functions. Because in recent years, the presence of MLG was reported also for plant groups different than Poales, including some liverworts, Selaginella $[2,40]$, horsetails $[47,65,85,86]$ and CGA [57], it seems that the evolution of MLG biosynthesis is more complicated. In CGA, the presence of two Csl genes was noted: $C s l C$ and 
CslD, which exact functions have not been determined yet, but theoretically they may be responsible for the MLG synthesis. The CslD gene is the ancestor of the CslF family, which encodes known MLG synthases in grasses [26], therefore CslD are likely to perform this function in CGA. The other possibility is that MLG in CGA is synthesized by a different, convergent biosynthetic pathway comparing to grasses, which can be independent of Csls [11]. The presence of MLG in other phylogenetically distant organisms [12], which emerged before the divergence of known MLG synthases: CslF, CslH, CslJ, is an additional support for the hypothesis of multiple origins of this polymer [85].

Lack of conservation of MLG synthesis during evolution, and the relatively rare occurrence of this polysaccharide in different groups of plants, indicates that although the MLG biosynthetic pathway existed in a direct algal ancestor of land plants, the presence of this glucan was not necessary for terrestrialization. It seems more likely, that the MLG biosynthesis have a specific, not fully understood yet, significance for adaptation to certain environmental conditions or to specific functions [12]. In addition, not only the biosynthetic pathway, but also the MLG function could have changed during evolution and differ between ancient CGA, horsetails and most modern monocots - Poales.

Many hemicelluloses of the cell walls of land plants are synthesized by Csls [24], but so far there is no evidence for their contribution to the xylan biosynthesis [87]. Possibly, the xylan biosynthesis can be carried out by a pathway independent of Csl, involving other glycosyltransferases (GTs). Recent studies show that in the biosynthesis of the xylan backbone are involved mainly IRX10/IRX10L [88-90], belonging to the glycosyltransferases family 47 (GT47), which have the xylan xylosyltransferase activity and can function together with other proteins, such as IRX9/IRX9L, IRX14/IRX14L [58,69,89,91-93] belonging to the GT43 family. Phylogenetic analyzes have shown that both Selaginella and Physcomitrella have orthologs of IRX10, as well as IRX14/IRX14L and IRX9L, suggesting that the mechanism of 1,4-B-D-xylan biosynthesis could be conserved in evolution. Interestingly, Ostreococcus (the smallest known eukaryote) contains several genes of GT43 families, which are known as those involved in the synthesis of 1,4- $B-D$-xylan $[91,94,95]$. It is therefore possible, that the process of $1,4-\beta-D$-xylan biosynthesis preceded the evolution of land plant lineage [22].

\section{Hemicelluloses rearrangement in cell wall}

In the land plant lineage, changes in the hemicelluloses composition are associated with the alterations of their metabolism. Particularly important for the terrestrial plants evolution seems to be the mechanisms, that modifies the cell wall structure enabling its expansion what in turn increase the overall plant size. Experimental studies on seed plants showed that in the cell wall expansion xyloglucan endotransglycosylases/hydrolases (XTH) are involved, for which the xyloglucan is a substrate $[96,97]$. XTH belong to the group of glycoside hydrolases GH16, and have two different enzymatic activities: the activity of xyloglucan endohydrolase $(\mathrm{XEH})$, which enables the hydrolysis of xyloglucan backbone, and the activity of xyloglucan endotransglycosylase
(XET), resulting in the interpolymer grafting between two xyloglucan molecules [98]. Structural and phylogenetic analyses showed that XEH evolved secondarily with XET being the ancestral one [99].

The XET activity is necessary for the cell wall expansion, when the sliding of cellulose microfibrils occur due to the relaxation of an integral cellulose-xyloglucan network [41]. XTHs cut and try to connect the associated xyloglucans with other available xyloglucans (XET activity), causing a reorganization of the cell wall, which enabling its growth [41]. XTH and xyloglucan are present in all land plants and the XET activity was shown to be significantly correlated with the intensively growing cells and/or tissues $[8,100]$. Interestingly, in CGA, the algal ancestors of land plants, despite the absence of confirmed xyloglucan, the presence of XET activity was detected [41]. This means, that XTH probably emerged in the evolution before its known substrate - xyloglucan. It is assumed that the ancestral XTH had lower substrate specificity and therefore initially was able to act on other hemicelluloses [100]. Because phylogenetic and structural relations between XTHs, xylan endohydrolases and $(1,3-1,4)-\beta$-D-endoglucanases $[41,101]$ have been showed in many studies, it seems likely that xylans [101] or MLGs [41] can be the substrates for ancestral XET/XTH. In light of these assumptions, results of the research on Ulva linza, belonging to chlorophycean algae, which is more evolutionarily distant from terrestrial plants than CGA, are extremely interesting. In this species, the cell wall has cellulose microfibrils associated with polysaccharides similar to XyG [102], which have mixed bonds resembling MLG (mixed-linkage xyloglucan-like polysaccharide) $[46,103]$. Possibility, that this polysaccharide had a common ancestor with MLG and xyloglucan from the land plants lineage, is intriguing. The most interesting however is the XET activity found in this species [104]. The polysaccharide with mixed features of XyG and MLG is a putative substrate for this XET activity in Ulva. It is also a substrate for $(1,3-1,4)-B$-D-glucan endohydrolases, what confirms the evolutionary relationships between XTHs and (1,3-1,4)-ß-D-glucan endohydrolases [41]. An additional confirmation of these associations is the recent discovery in Populus trichocarpa of the unique endohydrolases with the broad substrate specificity, able to cleave different linear glucans such as MLGs, cello-oligosaccharides and highly branched oligo- and polysaccharides of xyloglucan. These hydrolases have features of both XTH and $(1,3-1,4)-\beta-\mathrm{D}$ glucan endohydrolases [105]).

Many studies showed that XTH enzyme and hemicelluloses changed in order to adjust the XET activity and its substrate for the optimal growth of cell walls. The ultimate result, a XTH/xyloglucan system, was probably a key event for successful expansion to the land, as confirmed by the fact that during further evolution and diversification of land plants, this system was highly conserved $[41,101]$.

In this context, extremely puzzling seems to be the possibility that the XTH/xyloglucan system lost its importance in commelinoid monocots, where the XET activity lost its strong substrate specificity [101]. In this group of plants, xyloglucan is present only in a small amount, what is surprising regarding the great abundance of XTH genes and the high level of XET activity. Recent studies indicate that 
the substrates for XET activity in these plants may be not only xyloglucans, but also dominating in their cell walls glucuronoarabinoxylan and/or MLG [101].

In green algae and horsetails, which contain MLG, another transglycosylation activity the MXE (MLG: xyloglucan endotransglycosylase) has recently been found, which is responsible for the graft of MLG to xyloglucan [106]. This activity is distinct from the XET activity. MXE localization in horsetails showed that, in contrast to the XET activity detected in young growing tissues, MXE is present only in mature organs, possibly reinforcing the cell walls in senescent tissues [106,107]. In grasses, in which MLG is an abundant component of cell walls, the MXE activity is either absent or very low, and probably connected with XTH [108], because the active MXE proteins were not found in these plants [107]. In seed plants that do not have MLG, both functions, i.e. the loosening as well as the strengthening of cell wall structure, seem to be conducted by XTHs $[44,96,109]$. Perhaps, XTHs perform the same functions in grasses, as in these plants the MXE proteins were not detected.

Many recent studies show, that many other endohydrolases occur in plants, which like XTH and MXE have the hydrolase and endotransglycosylase activities [39]. Relatively recent discovery provided information that among others, for example endo- $\beta$-mannanases belonging to the family 5 of glycoside hydrolases (GH5) have both of these activities [51]. Their activity as mannan endotranglycosylases was detected in many species of seed plants, and the first such an enzyme was isolated from the tomato fruit which was found to belong to the multigene family. For the genes encoding the endo-beta-mannanases having the hydrolase and transglycosylase activity the name MTH (mannan transglycosylase/hydrolase) was proposed [51]. Phylogenetic analysis of endo- $\beta$-mannanases showed that the plant MTHs are related with fungal, bacterial and animal enzymes, suggesting their ancient evolutionary origin. In contrast, the diversifications of MTHs have probably occurred already after the separation of the plants from the other groups of organisms [92].

Another group of recently discovered and still poorly known enzymes, which possess hydrolase and endotransglycosylase activity are endo- $\beta$ - 1,4 -xylanases, belonging to the family 10 of glycoside hydrolases (GH10). The xylan endotransglycosylation activity was found in both, the primary cell walls of the many seeds plants and representatives of basal land plants [39], as well as in the secondary walls of poplar [95]. Endo- $\beta$-1,4-xylanases probably are involved in the modification of the xylan in primary and secondary cell walls. Their exact function had not been explained yet, although recent studies have shown that in the secondary wood they are likely to be responsible for the releases tension in the secondary cell walls [95]. Because xylan endotransglycosylation activity is a relatively recent discovery, currently little is known about its emergence in the evolutionary aspect.

\section{Pectins - important polysaccharides of the primary cell wall}

Pectins are acidic polysaccharides of primary cell walls of all land plants, where they play different functions. The most important seems to be the regulation of cell adhesion
$[110,111]$, which is essential for the development and functioning of multicellular organisms, as land plants. Pectins participate also in the apical and diffusive growth of cells [112], are involved in the defense response against pathogens [113] and regulate the cell wall strengthening [114]. In seed plants, three main groups of pectins are distinguished: homogalacturonan (HG), rhamnogalacturonan I (RG-I) and rhamnogalacturonan II (RG-II) [113]. Sometimes, as the fourth separate group, the xylogalacturonans (XGA) are also given $[112,115]$.

Pectins are abundant already in CGA, occurring even in single-celled ones, as Penium margaritaceum $[49,112]$. The presence of pectin in the ancestors of land plants suggests they importance for the expansion of land or at least for the development of first non-vascular land plants, which contain much more pectins than more evolutionarily advanced vascular plants. In the latter, the amount of pectins, in relation to the bryophytes, is markedly reduced [49], but they still remain one of the major components of the cell wall, essential for the proper cell wall functioning. Pectic polysaccharides, as components of cell walls, are generally conserved during the evolution of land plants, although minor structural differences in the side chains occur.

The main pectic component of the cell wall of land plants is $\mathrm{HG}$, which may be also the polysaccharide backbone for branched pectin types, such as XGA and RG-II [112]. HG is an important structural component of the primary cell walls, since the pair of HG molecules interconnected by $\mathrm{Ca}^{2+}$ bridges stiffens the walls [114]. Homogalacturonan seems to be the primary pectin, because it occurs not only in land plants, but also in CGA $[11,116,117]$, where as in embryophytes it may be bridged by calcium. In addition, the distribution of HG epitopes with different degree of esterification with methanol suggests, that in tested algae species, similarly to embryophytes, methyl-esterification is associated with processes of cell growth and differentiation $[46,117,118]$.

RG-Is are pectins widely conserved in land plants and present only in some more evolutionary advanced charophycean green algae [57], suggesting that they originated later than HG. Their branched structure enables modifications of the side chains, resulting in the structural diversity of this group of pectins [113].

RG-II molecules can be cross-linked through the boron ester bonds between the side chains [119]. Reduced ability to form the RG-II dimmers leads to dwarfism, indicating the importance of RG-II cross-linking for plant growth [120]. RG-II occurs almost exclusively in vascular plants $[49,121,122]$. In bryophytes, if found it occurs in a very small amount [122]. The RGII level in the cell walls appears to increase with the ongoing evolution of vascular plants, and this trend is likely to correlate with an increase in upward growth and the ability to form lignified secondary cell walls [122]. Therefore, RG II is considered to be an evolutionary innovation of land plants, which enabled the development and expansion of vascular plants.

The RG-II structure is highly conserved [112,123], although some seed tracheophytes have RG-II where the L-rhamnose residue is replaced by 3-O-metylrhamnose [11]. Despite the fact that RG-II is characteristic of the terrestrial 
plants [112], some rare sugar residues in RG-II, like 3-deoxyD-manno-2-octulosonic acid (KDO) [124], were also found in scales of prasinophycean algae $[124,125]$. Furthermore, the sequence of CMP-KDO synthase, essential for the synthesis of KDO-containing polymers, was detected in both land plants and in gram-negative bacteria [126]. These results suggest that some sugar residues and some genes involved in the RG-II biosynthesis can be of more ancient origin than this polymer [12].

\section{Pectin metabolism}

Many of pectin specific features and the evolution of genes responsible for their biosynthesis and modifications are not fully elucidated [112]). The complicated structure and function of pectins require numerous genes, associated with their production and metabolism [115,127]. Many of pectin related genes have already been identified [112], but in most cases their exact function is not clear. Recent research on $P$. patens, as a species representing the early stage of the transition from water to land, have provided new data on the evolution of pectin metabolism and its importance for the development of land plants [112]. It has been found that five of the 16 analyzed pectin related gene families (homogalacturonan galacturonosyltransferases, polygalacturonases, pectin methylesterases, homogalacturonan methyltransferases, and pectate lyase-like proteins), form a multigene family already in the early terrestrial plants. This indicates that the pectin related genes diversification, occurred probably before the development of land plants [112]. These genes are associated mainly with HG - the most primary pectin, and their early diversification suggests complex function of this polysaccharide before the expansion of land [128]. Seven different gene families (UDP-rhamnose synthases, UDP-glucuronic acid epimerases, homogalacturonan galacturonosyltransferase-like proteins, $\beta$-1,4-galactan and $\beta$-1,4-galactosyltransferases, rhamnogalacturonan II xylosyltransferases, and pectin acetylesterases) were shown to have a single member in the common ancestor of land plants, and their subsequent diversification suggests its relation to the land expansion [112]. The last four families of 16 analyzed genes (xylogalacturonan xylosyltransferase, rhamnogalacturonan I arabinosyltransferase, pectin methylesterase inhibitor, or polygalacturonase inhibitor protein families) were not detected in P. patens [112]. These genes probably have emerged in the evolution later and therefore they could not be relevant for the early stages of the land colonization. They could have however contributed to the diversification of land plants, or more likely to cell specialization. This is indicated by the fact that the XGA (pectin) as well as XGA xylosyltransferase, responsible for its biosynthesis, are not present in $P$. patens [48], while in evolutionarily younger taxa they have a distinct, tissue-specific location.

\section{Lignin - phenol component important for terrestrialization}

The key evolutionary innovation that enabled the development of vascular plants that currently dominate in the terrestrial environment was the ability to produce lignified cell walls $[8,129,130]$. During land colonization, plants were exposed to various stresses, associated with the changes in the environment, such as UV radiation, mechanical stress, drying, and also to the co-evolution of herbivores and pathogens [131]. Lignin and the cell metabolism associated with lignin production were important adaptive factors, which helped to overcome most of these problems and resulted in the rapid development and evolutionary success of land plants. The first land plants that did not form lignin yet, had the primitive phenylpropanoids metabolism, which allowed them to accumulate simple phenylpropanoids, playing a role in the protection from UV radiation. The cell wall lignification, which appeared later in the evolution, gave plants the mechanical strength enabling the vertical growth, thereby improving access to the light and efficient photosynthesis, which in turn led to a significant increase in the plant body size [132]. Lignin, through strengthening the water-conducting cells, contributed to the formation of the efficient long-distance conducting system [12,133]. Furthermore, lignin is one of the most difficult to degrade biopolymers, so that it constitutes an effective protection against pathogens and herbivores, which have been evolving together with vascular plants $[134,135]$.

Lignin is a three-dimensional phenolic hetero-polymer which by crosslinking the cellulose and hemicellulose impregnates cell walls $[15,109,136]$ to provide them with mechanical strength [137]. It is polymerized by oxidative coupling mainly of three p-hydroxycinnamyl alcohols as a result of enzymatic reaction catalyzed by laccases and class III of plant peroxidases [138-141]. As a result, hydrophobic heteropolymers are produced, consisting of $\mathrm{H}$ (p-hydroxyphenyl), G (guaiacyl) and S (syringyl) subunits originating from p-coumaryl, coniferyl and sinapyl alcohols, respectively [141,142].

Lignins are present in all Tracheophyta. However, the different groups of extant vascular plants differ in the composition and arrangement of lignin monomers, deposited in their cell walls [132]. In addition, various cell types may also differ in lignin composition. In most gymnosperm plants studied, lignins are typically composed of $\mathrm{G}$ subunits with a small amount of $\mathrm{H}$ subunits. In angiosperms, besides $\mathrm{G}$ and $\mathrm{H}$ subunits, additionally a large ratio of $\mathrm{S}$ lignin monomers is present $[143,144]$, that were previously regarded as the evolutionary innovation in this group of plants. However, the presence of S lignin was reported also in representatives of other Tracheophyta groups, like all living gnetophytes, some lycophytes, ferns and gymnosperms [141]. The presence of S lignin in so phylogenetically distant groups of plants, and sometimes only in some species within them, can hypothetically be explained by the loss of the ability of $S$ lignin biosynthesis in some taxa or as the example of convergent biosynthetic pathways [132]. Biochemical studies indicate the latter possibility, arguing that the S lignin biosynthetic pathways differ in various groups of plants [145]. Interestingly even more complex composition of lignin is present in grasses [142], because besides of the G, S, and $H$ subunits of the p-hydroxycinnamyl alcohol they contain additionally a significant amount of ester related subunits of $\mathrm{p}$-coumaric acids [141]. 
Lignin is considered as the characteristic feature of tracheophytes, although there are some early and highly controversial studies [146], reporting the presence of lignin or compounds similar to lignin, in non-vascular plants such as brown algae, charophycean green algae and mosses [147-149]. The presence of lignin in brown algae and green algae has never been confirmed though. Despite the recent detection of epitopes associated with lignin in Nitella [150], charophycean green algae, now it is assumed that true lignin is not present in CGA [151]. However, the presence of these epitopes indicates that the primitive form of phenylpropanoids metabolism may already occur in chlorophycean, before the colonization of land by plants [132]. Epitopes associated with lignin were also detected in certain mosses, including Sphagnum cuspidatum, where the intensity of the fluorescent labeling of antibodies is similar to the control tracheophytes [150]. Bryophytes have already been known as those producing the phenylpropanoid compounds associated with precursors of lignin [49], but the presence of the true lignin in mosses is still rather controversial. Contemporary results obtained for mosses suggest, however, that the ability to transport and accumulate polymerized phenolic compounds in the cell walls could evolve even in non-vascular terrestrial plants. These phenolic compounds, which in some cases are similar to the true lignin, can exist as polyphenols associated with the cell wall [132].

In light of these assumptions the recent finding of the secondary wall and lignin in red algae Calliarthron cheilosporioides was very surprising, because the last common ancestor of red algae and land plants is dated for more than 1.3 billion years ago [152]. Moreover, lignins present in Calliarthron are highly specialized, as they have all three G, $\mathrm{H}$ and $\mathrm{S}$ subunits and a composition typical of angiosperms [152]. The homology of all three types of lignin monomers in Calliarthron and vascular plants could indicate their deeply conserved evolution, what is difficult to imagine given the phylogenetic distance between these groups and more than a billion years of independent evolution. More likely, the presence of lignin in Calliarthron could be explained by the convergent evolution [152]. Such convergent evolution of $S$ lignin biosynthesis probably occurred in the case of lycopods and angiosperms [22], as S lignins in these two groups are not homologous and they are synthesized by distinctly different biosynthetic pathways $[132,145]$. However, in the case of Calliarthron, where all three types of lignin can be found in the cell wall, convergent evolution would imply the simultaneous evolution of all lignin biosynthetic pathways, which seems unlikely. Therefore, it is not determined yet whether the presence of lignin in Callianthron is a result of inheritance or convergent evolution [12].

\section{Lignin biosynthesis}

Lignin is synthesized in two main steps: monoligol biosynthesis and their assembly in lignin polymers, and next their subsequent attachment to the hemicellulose and cellulose [151]. Peroxidases and laccases are enzymes considered as those involved in dimerization of monolignols and their incorporation to lignin, although these mechanisms are not fully elucidated [153]. Biochemical pathways of monolignols biosynthesis are highly conserved in vascular plants [151].
Based on the recent analyses of genes involved in the lignin biosynthesis it has been suggested that at last two distinct turning points in their evolution existed [151]. The first one was probably the appearance of the complete lignin biosynthetic pathway, with all nine gene families involved in this process, in mosses. Furthermore, the sudden expansion in number of these gene families' members occurred in this group of plants [151]. These results indicate that mosses are not only the basal line of terrestrial plants, but also a key point in the evolution of tracheophytes [154].

The second turning point for the lignin biosynthesis was the emergence of the $\mathrm{F} 5 \mathrm{H}$ gene family, encoding P450 enzymes that convert $\mathrm{G}$ monolignol to $\mathrm{S}$ monolignol in angiosperms, increasing the number of different monomers and therefore increasing lignin diversity and complexity in the cell walls [155]. The F5H genes occurrence could lead to the formation of specialized cell phenotypes and morphological diversity in angiosperms [151]. However, reports on the S lignin presence in lycophytes and Ginkgo are contradictory to the assumption that $\mathrm{F} 5 \mathrm{H}$ occurs exclusively in angiosperms. Furthermore, in a representative of lycophyte, Selaginella moellendorffi, a novel SmF5H gene was identified, that is involved in the $\mathrm{S}$ lignin biosynthesis $[132,145]$. It has been shown that SmF5H has the phenylpropanoid 3-hydroxylase activity, the catalytic property absent in angiosperms, proving a difference in the strategy of S lignin biosynthesis in these two plant groups [132]. These results, as well as the phylogenetic analysis, suggest that $\mathrm{SmF5H}$ evolved independently of $\mathrm{F} 5 \mathrm{H}$ in angiosperms, and probably comes from the independent radiation of $\mathrm{P} 450$ enzymes, unique to lycophytes [145]. This finding supports the hypothesis that the S lignin may has evolved many times in different lines of vascular plants [151].

The expansion of most gene families, involved in lignin biosynthesis was correlated with the substrate diversity and occurred mostly already after the divergence of monocots and dicots [151], significantly increasing the diversity of cell walls. This somehow correlates with the mechanisms of defense against pathogens [151], because more varied and unpredictable lignin structure in the cell walls increases the chance of protection against its degradation.

\section{Conclusions}

The cell wall of the extant land plants is a structure with very diverse and complex composition. Although it is still not clear, whether the changes in the cell walls were the primary factors enabling adaptation to the changing environmental conditions or they were a secondary effect of the adaptation to new habitats, undoubtedly changes in the chemistry of the cell wall accompanied the main steps in the evolution of land [156]. Entirely new possibilities opened up, causing the acceleration of the evolution, and contributing to a multi-level diversification among extant land plants. One of the first key innovations was indisputably the emergence of polysaccharide-rich cell walls. Subsequent evolutionary events, such as e.g. the emergence of multicellularity and the cell elongation mechanism, terrestrialization process, 
vascularization and lignification, were closely related to changes in these polysaccharide-rich cell walls.

Currently there are several projects aimed at understanding the evolution of a variety of cell walls, including the ancestral groups of plants, which deliver new and surprising discoveries verifying various hypotheses concerning the cell

\section{Acknowledgments}

This work has not been funded from additional sources.

\section{Competing interests}

No competing interests have been declared.

\section{References}

1. Becker B, Marin B. Streptophyte algae and the origin of embryophytes. Ann Bot. 2009;103(7):999-1004. http://dx.doi.org/10.1093/ aob/mcp044

2. Sørensen I, Pettolino FA, Bacic A, Ralph J, Lu F, O’Neill MA, et al. The charophycean green algae provide insights into the early origins of plant cell walls. Plant J. 2011;68(2):201-211. http://dx.doi. org/10.1111/j.1365-313X.2011.04686.x

3. Rubinstein CV, Gerrienne P, de la Puente GS, Astini RA, Steemans P. Early Middle Ordovician evidence for land plants in Argentina (eastern Gondwana). New Phytol. 2010;188(2):365-369. http://dx.doi. org/10.1111/j.1469-8137.2010.03433.x

4. Sanderson MJ, Thorne JL, Wikstrom N, Bremer K. Molecular evidence on plant divergence times. Am J Bot. 2004;91(10):1656-1665. http:// dx.doi.org/10.3732/ajb.91.10.1656

5. Wodniok S, Brinkmann H, Glöckner G, Heidel AJ, Philippe H, Melkonian $\mathrm{M}$, et al. Origin of land plants: do conjugating green algae hold the key? BMC Evol Biol. 2011;11(1):104. http://dx.doi. org/10.1186/1471-2148-11-104

6. Karol KG, McCourt RM, Cimino MT, Delwiche CF. The closest living relatives of land plants. Science. 2001;294(5550):2351-2353. http:// dx.doi.org/10.1126/science.1065156

7. McCourt RM, Delwiche CF, Karol KG. Charophyte algae and land plant origins. Trends Ecol Evol. 2004;19(12):661-666. http://dx.doi. org/10.1016/j.tree.2004.09.013

8. Kenrick P, Crane PR. The origin and early evolution of plants on land. Nature. 1997;389(6646):33-39. http://dx.doi.org/10.1038/37918

9. Niklas KJ, Kutschera U. The evolution of the land plant life cycle. New Phytol. 2010;185(1):27-41. http://dx.doi. org/10.1111/j.1469-8137.2009.03054.x

10. Domozych DS, Ciancia M, Fangel JU, Mikkelsen MD, Ulvskov P, Willats WGT. The cell walls of green algae: a journey through evolution and diversity. Front Plant Sci. 2012;3:82. http://dx.doi.org/10.3389/ fpls.2012.00082

11. Sørensen I, Domozych D, Willats WGT. How have plant cell walls evolved? Plant Physiol. 2010;153(2):366-372. http://dx.doi. org/10.1104/pp.110.154427

12. Popper ZA, Michel G, Hervé C, Domozych DS, Willats WGT, Tuohy MG, et al. Evolution and diversity of plant cell walls: from algae to flowering plants. Annu Rev Plant Biol. 2011;62(1):567-590. http:// dx.doi.org/10.1146/annurev-arplant-042110-103809

13. Bacic A, Harris PJ, Stone BA. Structure and function of plant cell walls. In: Preiss J, editor. The biochemistry of plants. New York, NY: Academic Press; 1988. p. 297-371. (vol 14).

14. O’Neill M, Albersheim P, Darvill A. The pectic polysaccharides of primary cell wall. In: Dey PM, editor. Methods in plant biochemistry. London: Academic Press; 1990. p. 415-441. (vol 2).

15. Carpita NC, Gibeaut DM. Structural models of primary cell walls in flowering plants: consistency of molecular structure with the physical properties of the walls during growth. Plant J. 1993;3(1):1-30. http:// dx.doi.org/10.1111/j.1365-313X.1993.tb00007.x

16. Ridley BL, O’Neill MA, Mohnen D. Pectins: structure, biosynthesis, and wall evolution. However, the full explanation, how plant cell walls originated and how they changed during the evolution of extant land plants, or how specialization of cells and cellular systems have arisen to perform certain functions, are still ahead of us.

oligogalacturonide-related signaling. Phytochemistry. 2001;57(6):929967. http://dx.doi.org/10.1016/S0031-9422(01)00113-3

17. Niklas KJ. The cell walls that bind the tree of life. Bioscience. 2004;54(9):831-841. http://dx.doi. org/10.1641/0006-3568(2004)054[0831:TCWTBT]2.0.CO;2

18. Adl SM, Simpson AGB, Farmer MA, Andersen RA, Anderson OR, Barta JR, et al. The new higher level classification of eukaryotes with emphasis on the taxonomy of protists. J Eukaryot Microbiol. 2005;52(5):399-451. http://dx.doi.org/10.1111/j.1550-7408.2005.00053.x

19. Bhattacharya D, Yoon HS, Hackett JD. Photosynthetic eukaryotes unite: endosymbiosis connects the dots. Bioessays. 2004;26(1):50-60. http://dx.doi.org/10.1002/bies.10376

20. Palmer JD, Soltis DE, Chase MW. The plant tree of life: an overview and some points of view. Am J Bot. 2004;91(10):1437-1445. http:// dx.doi.org/10.3732/ajb.91.10.1437

21. Baldauf SL. An overview of the phylogeny and diversity of eukaryotes. J Syst Evol. 2008;46(3):263-273.

22. Popper ZA, Tuohy MG. Beyond the green: understanding the evolutionary puzzle of plant and algal cell walls. Plant Physiol. 2010;153(2):373-383. http://dx.doi.org/10.1104/pp.110.158055

23. Baldan B, Andolfo P, Navazio L, Tolomio C, Mariani P. Cellulose in algal cell wall: an "in situ" localization. Eur J Histochem. 2001;45(1):51-56.

24. Yin Y, Huang J, Xu Y. The cellulose synthase superfamily in fully sequenced plants and algae. BMC Plant Biol. 2009;9(1):99. http:// dx.doi.org/10.1186/1471-2229-9-99

25. Nobles DR Jr, Brown RM Jr. Many paths up the mountain: tracking the evolution of cellulose biosynthesis. In: Brown RM Jr, Saxena IM, editors. Cellulose: molecular and structural biology. Dordrecht: Springer; 2007. p. 1-15.

26. Yin Y, Johns MA, Cao H, Rupani M. A survey of plant and algal genomes and transcriptomes reveals new insights into the evolution and function of the cellulose synthase superfamily. BMC Genomics. 2014;15(1):260. http://dx.doi.org/10.1186/1471-2164-15-260

27. Carroll A, Specht CD. Understanding plant cellulose synthases through a comprehensive investigation of the cellulose synthase family sequences. Front Plant Sci. 2011;2:5. http://dx.doi.org/10.3389/ fpls.2011.00005

28. Newman RH, Hill SJ, Harris PJ. Wide-angle $\mathrm{x}$-ray scattering and solid-state nuclear magnetic resonance data combined to test models for cellulose microfibrils in mung bean cell walls. Plant Physiol. 2013;163(4):1558-1567. http://dx.doi.org/10.1104/pp.113.228262

29. Tsekos I. The sites of cellulose synthesis in algae: diversity and evolution of cellulose-synthesizing enzyme complexes. J Phycol. 1999;35(4):635655. http://dx.doi.org/10.1046/j.1529-8817.1999.3540635.x

30. Nobles DR Jr, Brown RM Jr. The pivotal role of cyanobacteria in the evolution of cellulose synthases and cellulose synthaselike proteins. Cellulose. 2004;11(3-4):437-448. http://dx.doi. org/10.1023/B:CELL.0000046339.48003.0e

31. Roberts AW, Bushoven JT. The cellulose synthase (CESA) gene superfamily of the moss Physcomitrella patens. Plant Mol Biol. 2006;63(2):207-219. http://dx.doi.org/10.1007/s11103-006-9083-1

32. Roberts AW, Roberts EM, Delmer DP. Cellulose synthase (CesA) genes in the green alga Mesotaenium caldariorum. Eukaryot Cell. 2002;1(6):847-855. http://dx.doi.org/10.1128/EC.1.6.847-855.2002

33. Lewis LA, McCourt RM. Green algae and the origin of land plants. Am J Bot. 2004;91(10):1535-1556. http://dx.doi.org/10.3732/ajb.91.10.1535

34. Roberts AW, Roberts EM, Haigler $\mathrm{CH}$. Moss cell walls: structure and 
biosynthesis. Front Plant Sci. 2012;3:166. http://dx.doi.org/10.3389/ fpls.2012.00166

35. Wise HZ, Saxena IM, Brown RM. Isolation and characterization of the cellulose synthase genes PpCesA6 and PpCesA7 in Physcomitrella patens. Cellulose. 2011;18(2):371-384. http://dx.doi.org/10.1007/ s10570-010-9479-6

36. Tanaka K. Three distinct rice cellulose synthase catalytic subunit genes required for cellulose synthesis in the secondary wall. Plant Physiol. 2003;133(1):73-83. http://dx.doi.org/10.1104/pp.103.022442

37. Djerbi S, Lindskog M, Arvestad L, Sterky F, Teeri TT. The genome sequence of black cottonwood (Populus trichocarpa) reveals 18 conserved cellulose synthase (CesA) genes. Planta. 2005;221(5):739-746. http://dx.doi.org/10.1007/s00425-005-1498-4

38. Nairn CJ, Haselkorn T. Three loblolly pine CesA genes expressed in developing xylem are orthologous to secondary cell wall CesA genes of angiosperms. New Phytol. 2005;166(3):907-915. http://dx.doi. org/10.1111/j.1469-8137.2005.01372.x

39. Franková L, Fry SC. Phylogenetic variation in glycosidases and glycanases acting on plant cell wall polysaccharides, and the detection of transglycosidase and trans- $\beta$-xylanase activities. Plant J. 2011;67(4):662681. http://dx.doi.org/10.1111/j.1365-313X.2011.04625.x

40. Harholt J, Sørensen I, Fangel J, Roberts A, Willats WGT, Scheller HV, et al. The glycosyltransferase repertoire of the spikemoss Selaginella moellendorffi and a comparative study of its cell wall. PLoS ONE. 2012;7(5):e35846. http://dx.doi.org/10.1371/journal.pone.0035846

41. van Sandt VST, Stieperaere H, Guisez Y, Verbelen JP, Vissenberg $\mathrm{K}$. XET activity is found near sites of growth and cell elongation in bryophytes and some green algae: new insights into the evolution of primary cell wall elongation. Ann Bot. 2007;99(1):39-51. http:// dx.doi.org/10.1093/aob/mcl232

42. Vogel J. Unique aspects of the grass cell wall. Curr Opin Plant Biol. 2008;11(3):301-307. http://dx.doi.org/10.1016/j.pbi.2008.03.002

43. Mellerowicz EJ, Sundberg B. Wood cell walls: biosynthesis, developmental dynamics and their implications for wood properties. Curr Opin Plant Biol. 2008;11(3):293-300. http://dx.doi.org/10.1016/j. pbi.2008.03.003

44. Nishikubo N, Takahashi J, Roos AA, Derba-Maceluch M, Piens $\mathrm{K}$, Brumer $\mathrm{H}$, et al. XET-mediated xyloglucan rearrangements in developing wood of hybrid aspen. Plant Physiol. 2011;155:399-413. http://dx.doi.org/10.1104/pp.110.166934

45. Scheller HV, Ulvskov P. Hemicelluloses. Annu Rev Plant Biol. 2010;61(1):263-289. http://dx.doi.org/10.1146/ annurev-arplant-042809-112315

46. Popper ZA. Primary cell wall composition of bryophytes and charophytes. Ann Bot. 2003;91(1):1-12. http://dx.doi.org/10.1093/aob/ mcg013

47. Fry SC, Nesselrode BHWA, Miller JG, Mewburn BR. Mixed-linkage $(1 \rightarrow 3,1 \rightarrow 4)-\beta$-D-glucan is a major hemicellulose of Equisetum (horsetail) cell walls. New Phytol. 2008;179(1):104-115. http://dx.doi. org/10.1111/j.1469-8137.2008.02435.x

48. Moller I, Sørensen I, Bernal AJ, Blaukopf C, Lee K, Øbro J, et al. High-throughput mapping of cell-wall polymers within and between plants using novel microarrays: glycan microarrays for plant cell-wall analysis. Plant J. 2007;50(6):1118-1128. http://dx.doi. org/10.1111/j.1365-313X.2007.03114.x

49. Popper Z. Evolution and diversity of green plant cell walls. Curr Opin Plant Biol. 2008;11(3):286-292. http://dx.doi.org/10.1016/j. pbi.2008.02.012

50. Estevez JM, Fernandez PV, Kasulin L, Dupree P, Ciancia M. Chemi$\mathrm{cal}$ and in situ characterization of macromolecular components of the cell walls from the green seaweed Codium fragile. Glycobiology. 2008;19(3):212-228. http://dx.doi.org/10.1093/glycob/cwn101

51. Schröder R, Atkinson RG, Redgwell RJ. Re-interpreting the role of endo- $\beta$-mannanases as mannan endotransglycosylase/hydrolases in the plant cell wall. Ann Bot. 2009;104(2):197-204. http://dx.doi. org/10.1093/aob/mcp120

52. Chanzy HD, Grosrenaud A, Vuong R, Mackie W. The crystalline polymorphism of mannan in plant cell walls and after recrystallisation. Planta. 1984;161(4):320-329. http://dx.doi.org/10.1007/BF00398722
53. Mackie W, Preston RD. The occurrence of mannan microfibrils in the green algae Codium fragile and Acetabularia crenulata. Planta. 1968;79(3):249-253. http://dx.doi.org/10.1007/BF00396031

54. Whitney SEC, Brigham JE, Darke AH, Reid JSG, Gidley MJ. Structural aspects of the interaction of mannan-based polysaccharides with bacterial cellulose. Carbohydr Res. 1998;307(3-4):299-309. http:// dx.doi.org/10.1016/S0008-6215(98)00004-4

55. Hosoo Y, Imai T, Yoshida M. Diurnal differences in the supply of glucomannans and xylans to innermost surface of cell walls at various developmental stages from cambium to mature xylem in Cryptomeria japonica. Protoplasma. 2006;229(1):11-19. http://dx.doi.org/10.1007/ s00709-006-0190-2

56. Popper ZA, Fry SC. Primary cell wall composition of pteridophytes and spermatophytes. New Phytol. 2004;164(1):165-174. http://dx.doi. org/10.1111/j.1469-8137.2004.01146.x

57. Domozych DS, Sorensen I, Willats WGT. The distribution of cell wall polymers during antheridium development and spermatogenesis in the Charophycean green alga, Chara corallina. Ann Bot. 2009;104(6):1045-1056. http://dx.doi.org/10.1093/aob/mcp193

58. Pena MJ, Darvill AG, Eberhard S, York WS, O'Neill MA. Moss and liverwort xyloglucans contain galacturonic acid and are structurally distinct from the xyloglucans synthesized by hornworts and vascular plants. Glycobiology. 2008;18(11):891-904. http://dx.doi.org/10.1093/ glycob/cwn078

59. Hoffman M, Jia Z, Peña MJ, Cash M, Harper A, Blackburn AR, et al. Structural analysis of xyloglucans in the primary cell walls of plants in the subclass Asteridae. Carbohydr Res. 2005;340(11):1826-1840. http://dx.doi.org/10.1016/j.carres.2005.04.016

60. Hsieh YSY, Harris PJ. Xyloglucans of monocotyledons have diverse structures. Mol Plant. 2009;2(5):943-965. http://dx.doi.org/10.1093/ $\mathrm{mp} / \mathrm{ssp} 061$

61. Tuomivaara ST, Yaoi K, O’Neill MA, York WS. Generation and structural validation of a library of diverse xyloglucan-derived oligosaccharides, including an update on xyloglucan nomenclature. Carbohydr Res. 2015;402:56-66. http://dx.doi.org/10.1016/j.carres.2014.06.031

62. Smith BG, Harris PJ. The polysaccharide composition of Poales cell walls. Biochem Syst Ecol. 1999;27(1):33-53. http://dx.doi.org/10.1016/ S0305-1978(98)00068-4

63. Sarkar P, Bosneaga E, Auer M. Plant cell walls throughout evolution: towards a molecular understanding of their design principles. J Exp Bot. 2009;60(13):3615-3635. http://dx.doi.org/10.1093/jxb/erp245

64. Trethewey JAK, Campbell LM, Harris PJ. $(1 \rightarrow 3),(1 \rightarrow 4)-\beta$-D-glucans in the cell walls of the Poales (sensu lato): an immunogold labeling study using a monoclonal antibody. Am J Bot. 2005;92(10):1660-1674. http://dx.doi.org/10.3732/ajb.92.10.1660

65. Sørensen I, Pettolino FA, Wilson SM, Doblin MS, Johansen B, Bacic A, et al. Mixed-linkage $(1 \rightarrow 3),(1 \rightarrow 4)-\beta$-D-glucan is not unique to the Poales and is an abundant component of Equisetum arvense cell walls. Plant J. 2008;54(3):510-521. http://dx.doi. org/10.1111/j.1365-313X.2008.03453.x

66. Bell PR. Green plants: their origin and diversity. 2nd ed. Cambridge: Cambridge University Press; 2000.

67. Hodson MJ, White PJ, Mead A, Broadley MR. Phylogenetic variation in the silicon composition of plants. Ann Bot. 2005;96(6):1027-1046. http://dx.doi.org/10.1093/aob/mci255

68. Carafa A, Duckett JG, Knox JP, Ligrone R. Distribution of cell-wall xylans in bryophytes and tracheophytes: new insights into basal interrelationships of land plants. New Phytol. 2005;168(1):231-240. http://dx.doi.org/10.1111/j.1469-8137.2005.01483.x

69. York W, Oneill M. Biochemical control of xylan biosynthesis - which end is up? Curr Opin Plant Biol. 2008;11(3):258-265. http://dx.doi. org/10.1016/j.pbi.2008.02.007

70. Kulkarni AR, Peña MJ, Avci U, Mazumder K, Urbanowicz BR, Pattathil S, et al. The ability of land plants to synthesize glucuronoxylans predates the evolution of tracheophytes. Glycobiology. 2012;22(3):439-451. http://dx.doi.org/10.1093/glycob/cwr117

71. Lahaye M, Robic A. Structure and functional properties of ulvan, a polysaccharide from green seaweeds. Biomacromolecules. 2007;8(6):1765-1774. http://dx.doi.org/10.1021/bm061185q 
72. Painter TJ, Aspinall GO. Algal polysaccharides. In: The polysaccharides. New York, NY: Academic Press; 1983. p. 195-285. (vol 2).

73. Turvey JR, Williams EL. The structures of some xylans from red algae. Phytochemistry. 1970;9(11):2383-2388. http://dx.doi.org/10.1016/ S0031-9422(00)85744-1

74. Richmond TA. The cellulose synthase superfamily. Plant Physiol. 2000;124(2):495-498. http://dx.doi.org/10.1104/pp.124.2.495

75. Keegstra K, Walton J. Plant science. Beta-glucans - brewer's bane, dietician's delight. Science. 2006;311(5769):1872-1873. http://dx.doi. org/10.1126/science. 1125938

76. Liepman AH, Wilkerson CG, Keegstra K. Expression of cellulose synthase-like $(C s l)$ genes in insect cells reveals that CslA family members encode mannan synthases. Proc Natl Acad Sci USA. 2005;102(6):2221-2226. http://dx.doi.org/10.1073/pnas.0409179102

77. Lerouxel O, Cavalier DM, Liepman AH, Keegstra K. Biosynthesis of plant cell wall polysaccharides - a complex process. Curr Opin Plant Biol. 2006;9(6):621-630. http://dx.doi.org/10.1016/j.pbi.2006.09.009

78. Cocuron JC, Lerouxel O, Drakakaki G, Alonso AP, Liepman AH, Keegstra $\mathrm{K}$, et al. A gene from the cellulose synthase-like $\mathrm{C}$ family encodes a beta-1,4 glucan synthase. Proc Natl Acad Sci USA. 2007;104(20):8550-8555. http://dx.doi.org/10.1073/pnas.0703133104

79. Verhertbruggen Y, Yin L, Oikawa A, Scheller HV. Mannan synthase activity in the CSLD family. Plant Signal Behav. 2011;6(10):1620-1623. http://dx.doi.org/10.4161/psb.6.10.17989

80. Yin L, Verhertbruggen Y, Oikawa A, Manisseri C, Knierim B, Prak $\mathrm{L}$, et al. The cooperative activities of CSLD2, CSLD3, and CSLD5 are required for normal Arabidopsis development. Mol Plant. 2011;4(6):1024-1037. http://dx.doi.org/10.1093/mp/ssr026

81. Burton RA, Wilson SM, Hrmova M, Harvey AJ, Shirley NJ, Medhurst A, et al. Cellulose synthase-like CslF genes mediate the synthesis of cell wall (1,3;1,4)- $\beta$-D-glucans. Science. 2006;311(5769):1940-1942. http://dx.doi.org/10.1126/science.1122975

82. Buschiazzo E, Ritland C, Bohlmann J, Ritland K. Slow but not low: genomic comparisons reveal slower evolutionary rate and higher $\mathrm{dN} /$ $\mathrm{dS}$ in conifers compared to angiosperms. BMC Evol Biol. 2012;12(1):8. http://dx.doi.org/10.1186/1471-2148-12-8

83. Burton RA, Jobling SA, Harvey AJ, Shirley NJ, Mather DE, Bacic A, et al. The genetics and transcriptional profiles of the cellulose synthaselike $\mathrm{H} v \mathrm{CslF}$ gene family in barley (Hordeum vulgare L.). Plant Physiol. 2008;146(4):1821-1833. http://dx.doi.org/10.1104/pp.107.114694

84. Doblin MS, Pettolino FA, Wilson SM, Campbell R, Burton RA, Fincher GB, et al. A barley cellulose synthase-like CSLH gene mediates $(1,3 ; 1,4)-\beta$-D-glucan synthesis in transgenic Arabidopsis. Proc Natl Acad Sci USA. 2009;106(14):5996-6001. http://dx.doi.org/10.1073/ pnas.0902019106

85. Burton RA, Fincher GB. $(1,3 ; 1,4)-\beta$-D-glucans in cell walls of the Poaceae, lower plants, and fungi: a tale of two linkages. Mol Plant. 2009;2(5):873-882. http://dx.doi.org/10.1093/mp/ssp063

86. Fincher GB. Exploring the evolution of $(1,3 ; 1,4)-\beta$-D-glucans in plant cell walls: comparative genomics can help! Curr Opin Plant Biol. 2009;12(2):140-147. http://dx.doi.org/10.1016/j.pbi.2009.01.002

87. Zhou HL, He SJ, Cao YR, Chen T, Du BX, Chu CC, et al. OsGLU1, a putative membrane-bound endo-1,4- $\beta$-D-glucanase from rice, affects plant internode elongation. Plant Mol Biol. 2006;60(1):137-151. http:// dx.doi.org/10.1007/s11103-005-2972-X

88. Ren Y, Hansen SF, Ebert B, Lau J, Scheller HV. Site-directed mutagenesis of IRX9, IRX9L and IRX14 proteins involved in xylan biosynthesis: glycosyltransferase activity is not required for IRX9 function in Arabidopsis. PLoS ONE. 2014;9(8):e105014. http://dx.doi. org/10.1371/journal.pone.0105014

89. Jensen JK, Johnson NR, Wilkerson CG. Arabidopsis thaliana IRX10 and two related proteins from psyllium and Physcomitrella patens are xylan xylosyltransferases. Plant J. 2014;80(2):207-215. http://dx.doi. org/10.1111/tpj.12641

90. Urbanowicz BR, Peña MJ, Moniz HA, Moremen KW, York WS. Two Arabidopsis proteins synthesize acetylated xylan in vitro. Plant J. 2014;80(2):197-206. http://dx.doi.org/10.1111/tpj.12643

91. Cantarel BL, Coutinho PM, Rancurel C, Bernard T, Lombard V, Henrissat $\mathrm{B}$. The carbohydrate-active enzymes database (CAZy): an expert resource for glycogenomics. Nucl Acids Res. 2009;37(database):D233D238. http://dx.doi.org/10.1093/nar/gkn663

92. Yuan JS, Yang X, Lai J, Lin H, Cheng ZM, Nonogaki H, et al. The endo- $\beta$-mannanase gene families in Arabidopsis, rice, and poplar. Funct Integr Genomics. 2006;7(1):1-16. http://dx.doi.org/10.1007/ s10142-006-0034-3

93. Brown DM, Goubet F, Wong VW, Goodacre R, Stephens E, Dupree P, et al. Comparison of five xylan synthesis mutants reveals new insight into the mechanisms of xylan synthesis. Plant J. 2007;52(6):1154-1168. http://dx.doi.org/10.1111/j.1365-313X.2007.03307.x

94. Lee C, Zhong R, Richardson EA, Himmelsbach DS, McPhail BT, Ye $\mathrm{ZH}$. The PARVUS gene is expressed in cells undergoing secondary wall thickening and is essential for glucuronoxylan biosynthesis. Plant Cell Physiol. 2007;48(12):1659-1672. http://dx.doi.org/10.1093/ $\mathrm{pcp} / \mathrm{pcm} 155$

95. Derba-Maceluch M, Awano T, Takahashi J, Lucenius J, Ratke C, Kontro I, et al. Suppression of xylan endotransglycosylase PtxtXyn10A affects cellulose microfibril angle in secondary wall in aspen wood. New Phytol. 2015;205(2):666-681. http://dx.doi.org/10.1111/nph.13099

96. Fry SC, Smith RC, Renwick KF, Martin DJ, Hodge SK, Matthews $\mathrm{KJ}$. Xyloglucan endotransglycosylase, a new wall-loosening enzyme activity from plants. Biochem J. 1992;282(pt 3):821-828.

97. Nishitani K, Tominaga R. Endo-xyloglucan transferase, a novel class of glycosyltransferase that catalyzes transfer of a segment of xyloglucan molecule to another xyloglucan molecule. J Biol Chem. 1992;267(29):21058-21064.

98. Nishitani K, Vissenberg K. Roles of the XTH protein family in the expanding cell. In: Verbelen JP, Vissenberg K, editors. The expanding cell. Berlin: Springer; 2006. p. 89-116. (Plant cell monographs). http:// dx.doi.org/10.1007/7089_2006_072

99. Baumann MJ, Eklof JM, Michel G, Kallas AM, Teeri TT, Czjzek M, et al. Structural evidence for the evolution of xyloglucanase activity from xyloglucan endo-transglycosylases: biological implications for cell wall metabolism. Plant Cell. 2007;19(6):1947-1963. http://dx.doi. org/10.1105/tpc.107.051391

100. Bateman RM, Crane PR, DiMichele WA, Kenrick PR, Rowe NP Speck T, et al. Early evolution of land plants: phylogeny, physiology, and ecology of the primary terrestrial radiation. Annu Rev Ecol Syst. 1998;29(1):263-292. http://dx.doi.org/10.1146/annurev. ecolsys.29.1.263

101. Strohmeier M, Hrmova M, Fischer M, Harvey AJ, Fincher GB, Pleiss J. Molecular modeling of family GH16 glycoside hydrolases: potential roles for xyloglucan transglucosylases/hydrolases in cell wall modification in the Poaceae. Protein Sci. 2009;13(12):3200-3213. http://dx.doi. org/10.1110/ps.04828404

102. Lahaye M, Jegou D, Buleon A. Chemical characteristics of insoluble glucans from the cell wall of the marine green alga Ulva lactuca (L.) Thuret. Carbohydr Res. 1994;262(1):115-125. http://dx.doi. org/10.1016/0008-6215(94)84008-3

103. Ray B, Lahaye M. Cell-wall polysaccharides from the marine green alga Ulva "rigida" (Ulvales, Chlorophyta). Chemical structure of ulvan. Carbohydr Res. 1995;274:313-318. http://dx.doi. org/10.1016/0008-6215(95)00059-3

104. Kim YH, Kim CY, Song WK, Park DS, Kwon SY, Lee HS, et al. Overexpression of sweetpotato swpa4 peroxidase results in increased hydrogen peroxide production and enhances stress tolerance in tobacco. Planta. 2008;227(4):867-881. http://dx.doi.org/10.1007/s00425-007-0663-3

105. Eklof JM, Shojania S, Okon M, McIntosh LP, Brumer H. Structurefunction analysis of a broad specificity Populus trichocarpa endo-glucanase reveals an evolutionary link between bacterial licheninases and plant XTH gene products. J Biol Chem. 2013;288(22):15786-15799. http://dx.doi.org/10.1074/jbc.M113.462887

106. Fry SC, Mohler KE, Nesselrode BHWA, Frankov L. Mixedlinkage $\beta$-glucan: xyloglucan endotransglucosylase, a novel wall-remodeling enzyme from Equisetum (horsetails) and charophytic algae. Plant J. 2008;55(2):240-252. http://dx.doi. org/10.1111/j.1365-313X.2008.03504.X

107. Mohler KE, Simmons TJ, Fry SC. Mixed-linkage glucan:xyloglucan endotransglucosylase (MXE) re-models hemicelluloses in Equisetum shoots but not in barley shoots or 
Equisetum callus. New Phytol. 2013;197(1):111-122. http://dx.doi. org/10.1111/j.1469-8137.2012.04371.x

108. Hrmova M, Farkas V, Lahnstein J, Fincher GB. A barley xyloglucan xyloglucosyl transferase covalently links xyloglucan, cellulosic substrates, and (1,3;1,4)- $\beta$-D-glucans. J Biol Chem. 2007;282(17):12951-12962. http://dx.doi.org/10.1074/jbc.M611487200

109. Cosgrove DJ. Growth of the plant cell wall. Nat Rev Mol Cell Biol. 2005;6(11):850-861. http://dx.doi.org/10.1038/nrm1746

110. Mouille G, Ralet MC, Cavelier C, Eland C, Effroy D, Hématy $\mathrm{K}$, et al. Homogalacturonan synthesis in Arabidopsis thaliana requires a Golgi-localized protein with a putative methyltransferase domain. Plant J. 2007;50(4):605-614. http://dx.doi. org/10.1111/j.1365-313X.2007.03086.x

111. Krupková E, Immerzeel P, Pauly M, Schmülling T. The TUMOROUS SHOOT DEVELOPMENT2 gene of Arabidopsis encoding a putative methyltransferase is required for cell adhesion and coordinated plant development. Plant J. 2007;50(4):735-750. http:// dx.doi.org/10.1111/j.1365-313X.2007.03123.x

112. McCarthy TW, Der JP, Honaas LA, dePamphilis CW, Anderson CT. Phylogenetic analysis of pectin-related gene families in Physcomitrella patens and nine other plant species yields evolutionary insights into cell walls. BMC Plant Biol. 2014;14(1):79. http://dx.doi. org/10.1186/1471-2229-14-79

113. Atmodjo MA, Hao Z, Mohnen D. Evolving views of pectin biosynthesis. Annu Rev Plant Biol. 2013;64(1):747-779. http://dx.doi. org/10.1146/annurev-arplant-042811-105534

114. Braccini I, Pérez S. Molecular basis of $\mathrm{Ca}^{2+}$-induced gelation in alginates and pectins: the egg-box model revisited. Biomacromolecules. 2001;2(4):1089-1096. http://dx.doi.org/10.1021/bm010008g

115. Mohnen D. Pectin structure and biosynthesis. Curr Opin Plant Biol. 2008;11(3):266-277. http://dx.doi.org/10.1016/j.pbi.2008.03.006

116. Proseus TE, Boyer JS. Calcium pectate chemistry controls growth rate of Chara corallina. J Exp Bot. 2006;57(15):3989-4002. http://dx.doi. org/10.1093/jxb/erl166

117. Domozych DS, Serfis A, Kiemle SN, Gretz MR. The structure and biochemistry of charophycean cell walls: I. Pectins of Penium margaritaceum. Protoplasma. 2007;230(1-2):99-115. http://dx.doi.org/10.1007/ s00709-006-0197-8

118. Eder M, Lütz-Meindl U. Analyses and localization of pectin-like carbohydrates in cell wall and mucilage of the green alga Netrium digitus. Protoplasma. 2010;243(1-4):25-38. http://dx.doi.org/10.1007/ s00709-009-0040-0

119. O’Neill MA, Warrenfeltz D, Kates K, Pellerin P, Doco T, Darvill AG, et al. Rhamnogalacturonan-II, a pectic polysaccharide in the walls of growing plant cell, forms a dimer that is covalently cross-linked by a borate ester. J Biol Chem. 1996;271(37):22923-22930. http://dx.doi. org/10.1074/jbc.271.37.22923

120. O'Neill MA, Eberhard S, Albersheim P, Darvill AG. Requirement of borate cross-linking of cell wall rhamnogalacturonan II for Arabidopsis growth. Science. 2001;294(5543):846-849. http://dx.doi.org/10.1126/ science.1062319

121. Perez S, Rodríguez-Carvajal MA, Doco T. A complex plant cell wall polysaccharide: rhamnogalacturonan II. A structure in quest of a function. Biochimie. 2003;85(1-2):109-121. http://dx.doi.org/10.1016/ S0300-9084(03)00053-1

122. Matsunaga T, Ishii T, Matsumoto S, Higuchi M, Darvill A, Albersheim $\mathrm{P}$, et al. Occurrence of the primary cell wall polysaccharide rhamnogalacturonan II in pteridophytes, lycophytes, and bryophytes. Implications for the evolution of vascular plants. Plant Physiol. 2004;134(1):339-351. http://dx.doi.org/10.1104/pp.103.030072

123. Pabst M, Fischl RM, Brecker L, Morelle W, Fauland A, Köfeler H, et al. Rhamnogalacturonan II structure shows variation in the side chains monosaccharide composition and methylation status within and across different plant species. Plant J. 2013;76:61-72. http://dx.doi. org/10.1111/tpj.12271

124. York WS, Darvill AG, McNeil M, Albersheim P. 3-deoxy-d-manno2 -octulosonic acid (KDO) is a component of rhamnogalacturonan II, a pectic polysaccharide in the primary cell walls of plants. Carbohydr Res. 1985;138(1):109-126. http://dx.doi.org/10.1016/0008-6215(85)85228-9
125. Becker B, Becker D, Kamerling JP, Melkonian M. 2-ketosugar acids in green flagellates: a chemical marker for prasinophycean scales. J Phycol. 1991;27(4):498-504. http://dx.doi. org/10.1111/j.0022-3646.1991.00498.x

126. Royo J, Gımez E, Hueros G. CMP-KDO synthetase: a plant gene borrowed from gram-negative eubacteria. Trends Genet. 2000;16(10):432433. http://dx.doi.org/10.1016/S0168-9525(00)02102-8

127. Harholt J, Suttangkakul A, Vibe Scheller H. Biosynthesis of pectin. Plant Physiol. 2010;153(2):384-395. http://dx.doi.org/10.1104/ pp. 110.156588

128. Willats WG, Orfila C, Limberg G, Buchholt HC, van Alebeek GJ, Voragen AG, et al. Modulation of the degree and pattern of methylesterification of pectic homogalacturonan in plant cell walls. Implications for pectin methyl esterase action, matrix properties, and cell adhesion. J Biol Chem. 2001;276(22):19404-19413. http://dx.doi. org/10.1074/jbc.M011242200

129. Peter G, Neale D. Molecular basis for the evolution of xylem lignification. Curr Opin Plant Biol. 2004;7(6):737-742. http://dx.doi. org/10.1016/j.pbi.2004.09.002

130. Boyce CK, Zwieniecki MA, Cody GD, Jacobsen C, Wirick S, Knoll $\mathrm{AH}$, et al. Evolution of xylem lignification and hydrogel transport regulation. Proc Natl Acad Sci USA. 2004;101(50):17555-17558. http://dx.doi.org/10.1073/pnas.0408024101

131. Raven JA. Physiological correlates of the morphology of early vascular plants. Biol J Linn Soc. 1984;88(1-2):105-126. http://dx.doi. org/10.1111/j.1095-8339.1984.tb01566.x

132. Weng JK, Chapple C. The origin and evolution of lignin biosynthesis. New Phytol. 2010;187(2):273-285. http://dx.doi. org/10.1111/j.1469-8137.2010.03327.x

133. Coleman HD, Samuels AL, Guy RD, Mansfield SD. Perturbed lignification impacts tree growth in hybrid poplar - a function of sink strength, vascular integrity, and photosynthetic assimilation. Plant Physiol. 2008;148(3):1229-1237. http://dx.doi.org/10.1104/pp.108.125500

134. Quentin M, Allasia V, Pegard A, Allais F, Ducrot PH, Favery B, et al. Imbalanced lignin biosynthesis promotes the sexual reproduction of homothallic oomycete pathogens. PLoS Pathog. 2009;5(1):e1000264. http://dx.doi.org/10.1371/journal.ppat.1000264

135. Yuan JS, Köllner TG, Wiggins G, Grant J, Degenhardt J, Chen F. Molecular and genomic basis of volatile-mediated indirect defense against insects in rice. Plant J. 2008;55(3):491-503. http://dx.doi. org/10.1111/j.1365-313X.2008.03524.X

136. Fry SC. Primary cell wall metabolism: tracking the careers of wall polymers in living plant cells. New Phytol. 2004;161(3):641-675. http://dx.doi.org/10.1111/j.1469-8137.2004.00980.x

137. Somerville C, Bauer S, Brininstool G, Facette M, Hamann T, Milne $\mathrm{J}$, et al. Toward a systems approach to understanding plant cell walls. Science. 2004;306(5705):2206-2211. http://dx.doi.org/10.1126/ science. 1102765

138. Boerjan W, Ralph J, Baucher M. Lignin biosynthesis. Annu Rev Plant Biol. 2003;54:519-546. http://dx.doi.org/10.1146/annurev. arplant.54.031902.134938

139. Boudet AM, Lapierre C, Grima-Pettenati J. Biochemistry and molecular biology of lignification. New Phytol. 1995;129(2):203-236. http:// dx.doi.org/10.1111/j.1469-8137.1995.tb04292.x

140. Barceló AR, Ros LVG, Gabaldón C, López-Serrano M, Pomar F, Carrión JS, et al. Basic peroxidases: the gateway for lignin evolution? Phytochem Rev. 2004;3(1-2):61-78. http://dx.doi. org/10.1023/B:PHYT.0000047803.49815.1a

141. Espiñeira JM, Novo Uzal E, Gómez Ros LV, Carrión JS, Merino F, Ros Barceló A, et al. Distribution of lignin monomers and the evolution of lignification among lower plants. Plant Biol. 2011;13(1):59-68. http:// dx.doi.org/10.1111/j.1438-8677.2010.00345.x

142. Ralph J, Bunzel M, Marita JM, Hatfield RD, Lu F, Kim H, et al. Peroxidase-dependent cross-linking reactions of p-hydroxycinnamates in plant cell walls. Phytochem Rev. 2004;3(1-2):79-96. http://dx.doi. org/10.1023/B:PHYT.0000047811.13837.fb

143. Jin Z, Matsumoto $Y$, Tange T, Akiyama T, Higuchi M, Ishii $\mathrm{T}$, et al. Proof of the presence of guaiacyl-syringyl lignin in 
Selaginella tamariscina. J Wood Sci. 2005;51(4):424-426. http:// dx.doi.org/10.1007/s10086-005-0725-8

144. Gómez Ros LV, Gabaldón C, Pomar F, Merino F, Pedreño MA, Barceló AR. Structural motifs of syringyl peroxidases predate not only the gymnosperm-angiosperm divergence but also the radiation of tracheophytes. New Phytol. 2007;173(1):63-78. http://dx.doi. org/10.1111/j.1469-8137.2006.01898.x

145. Weng JK, Li X, Stout J, Chapple C. Independent origins of syringyl lignin in vascular plants. Proc Natl Acad Sci USA. 2008;105(22):78877892. http://dx.doi.org/10.1073/pnas.0801696105

146. Lewis NG, Yamamoto E. Lignin: occurrence, biogenesis and biodegradation. Annu Rev Plant Physiol Plant Mol Biol. 1990;41(1):455-496. http://dx.doi.org/10.1146/annurev.pp.41.060190.002323

147. Siegel SM. Evidence for the presence of lignin in moss gametophytes. Am J Bot. 1969;56(2):175. http://dx.doi.org/10.2307/2440703

148. Reznikov VM, Mikhaseva M, Zil'bergleit M. The lignin of the alga Fucus vesiculosus. Chem Nat Comp. 1978;14:554-556.

149. Delwiche CF, Graham LE, Thomson N. Lignin-like compounds and sporopollenin Coleochaete, an algal model for land plant ancestry. Science. 1989;245(4916):399-401. http://dx.doi.org/10.1126/ science.245.4916.399

150. Ligrone R, Carafa A, Duckett JG, Renzaglia KS, Ruel K. Immunocytochemical detection of lignin-related epitopes in cell walls in bryophytes and the charalean alga Nitella. Plant Syst Evol. 2008;270(3-4):257-272. http://dx.doi.org/10.1007/s00606-007-0617-z
151. Xu Z, Zhang D, Hu J, Zhou X, Ye X, Reichel KL, et al. Comparative genome analysis of lignin biosynthesis gene families across the plant kingdom. BMC Bioinformatics. 2009;10(11 suppl):S3. http://dx.doi. org/10.1186/1471-2105-10-S11-S3

152. Martone PT, Estevez JM, Lu F, Ruel K, Denny MW, Somerville C, et al. Discovery of lignin in seaweed reveals convergent evolution of cell-wall architecture. Curr Biol. 2009;19(2):169-175. http://dx.doi. org/10.1016/j.cub.2008.12.031

153. Boudet AM, Kajita S, Grima-Pettenati J, Goffner D. Lignins and lignocellulosics: a better control of synthesis for new and improved uses. Trends Plant Sci. 2003;8(12):576-581. http://dx.doi.org/10.1016/j. tplants.2003.10.001

154. Nishiyama T, Fujita T, Shin-I T, Seki M, Nishide H, Uchiyama I, et al. Comparative genomics of Physcomitrella patens gametophytic transcriptome and Arabidopsis thaliana: implication for land plant evolution. Proc Natl Acad Sci USA. 2003;100(13):8007-8012. http:// dx.doi.org/10.1073/pnas.0932694100

155. Meyer K, Shirley AM, Cusumano JC, Bell-Lelong DA, Chapple C. Lignin monomer composition is determined by the expression of a cytochrome P450-dependent monooxygenase in Arabidopsis. Proc Natl Acad Sci USA. 1998;95(12):6619-6623.

156. Xue X, Fry SC. Evolution of mixed-linkage $(1 \rightarrow 3,1 \rightarrow 4)-\beta$-D-glucan (MLG) and xyloglucan in Equisetum (horsetails) and other monilophytes. Ann Bot. 2012;109(5):873-886. http://dx.doi.org/10.1093/ $\mathrm{aob} / \mathrm{mcs} 018$ 